\title{
EPIDEMIOLOGICAL CHARACTERISTICS OF LEPTOSPIROSIS IN VOJVODINA, SERBIA, 2009-2018, FROM THE ASPECT OF ONE HEALTH
}

\author{
Tatjana Pustahija ${ }^{1^{*}}$, Vladimir Vuković ${ }^{1}$, Mioljub Ristić ${ }^{1,2}$, Sara Savić ${ }^{3}$, \\ Živoslav Grgić ${ }^{3}$, Smiljana Rajčević' ${ }^{1,2}$, Mirjana Štrbac ${ }^{1}$, \\ Tanja Tomašević ${ }^{4,5}$, Snežana Medić1,2 \\ ${ }^{1}$ Institute of Public Health of Vojvodina, Centre for Disease \\ Control and Prevention, Novi Sad, Republic of Serbia \\ ${ }^{2}$ University of Novi Sad, Faculty of Medicine, Department \\ of Epidemiology, Novi Sad, Republic of Serbia \\ ${ }^{3}$ Scientific Veterinary Institute "Novi Sad", Department for Serology, \\ Immunology and Biochemistry, Novi Sad, Republic of Serbia \\ ${ }^{4}$ Institute of Public Health of Vojvodina, Centre for Analysis, Planning \\ and Organization of Health Care, Novi Sad, Republic of Serbia \\ ${ }^{5}$ University of Novi Sad, Faculty of Medicine, Department of Social Medicine \\ and Health Statistics with Informatics, Novi Sad, Republic of Serbia
}

\section{Abstract}

This study summarizes demographical and chronological characteristics of human leptospirosis and reveals the spatial distribution of this disease in the Autonomous Province of Vojvodina during the period 2009-2018, as well as examines possible relationships between the occurrence of the disease and climatic factors. Additionally, it describes the seroprevalence of the disease among domestic animals in the same area and the same period. Pearson's correlation was used to explore correlations between different meteorological factors and trends in time-series of human cases. Overall 87 human cases of leptospirosis and five subsequent deaths (Case Fatality Rate - CFR: 5.75\%) were recorded in the ten-year period. The average annual incidence rate was $0.45 / 100,000$ (range: $0.16-1.50 / 100,000)$. The disease was more prevalent in males $(\mathrm{M} / \mathrm{F}=16.40: 1)$, with the majority of cases reported in August $(\mathrm{N}=23 ; 26.44 \%)$, September $(\mathrm{N}=$ $20 ; 23 \%)$ and October $(\mathrm{N}=15 ; 17.24 \%)$. A statistically significant weak positive correlation was observed between the mean monthly air temperature and the

\footnotetext{
${ }^{1 *}$ Corresponding Author: tatjana.pustahija@izjzv.org.rs
} 
number of human cases of leptospirosis of the same month $(\mathrm{r}=0.30, p<0.01)$, and a statistically significant weak positive correlation was found between the number of human cases and the sum of precipitation in the previous month ( $\mathrm{r}$ $=0.27, p<0.01$ ). The average annual seroprevalence among domestic animals in total was $1.13 \%$ (range: $0.23-3.65 \%$ ). Seropositivity of tested samples of cats, dogs, cattle, donkeys, horses, sheep, pigs and goats was $25 \%, 9.50 \%, 8.55 \%, 6.25 \%$, $1.59 \%, 0.25 \%, 0.18 \%$, and 0.00 , respectively. Human and animal leptospirosis occurs continuously in Vojvodina, which implies the need for constant and thorough monitoring of the epidemiological and epizootic situation of this disease. Further, more comprehensive parallel studies in humans and animals are needed as well as additional studies of living conditions of animals on farms with leptospirosis, and more extensive studies that will determine the influence of climatic/ environmental factors on the occurrence of leptospirosis in Vojvodina.

Key words: Human leptospirosis, animal leptospirosis, zoonosis, epidemiology, seroprevalence, one health

\title{
EPIDEMIOLOŠKE KARAKTERISTIKE LEPTOSPIROZE U VOJVODINI, SRBIJA, U PERIODU 2009-2018 - SA ASPEKTA JEDNOG ZDRAVLJA
}

\author{
Tatjana Pustahija ${ }^{1}$, Vladimir Vuković ${ }^{1}$, Mioljub Ristić ${ }^{1,2}$, Sara Savić ${ }^{3}$, \\ Živoslav Grgićn ${ }^{3}$, Smiljana Rajčević ${ }^{1,2}$, Mirjana Štrbac ${ }^{1}$, \\ Tanja Tomašević ${ }^{4,5}$, Snežana Medić1,2
}

${ }^{1}$ Institut za javno zdravlje Vojvodine, Centar za kontrolu i prevenciju bolesti, Novi Sad, Republika Srbija

${ }^{2}$ Univerzitet u Novom Sadu, Medicinski fakultet, Katedra za socijalnu medicinu i zdravstvenu statistiku sa informatikom, Novi Sad, Republika Srbija

${ }^{3}$ Naučni institut za veterinarstvo "Novi Sad", Odeljenje za imunološkoserološka i biohemijska ispitivanja, Novi Sad, Republika Srbija

${ }^{4}$ Institut za javno zdravlje Vojvodine, Centar za analizu, planiranje i

organizaciju zdravstvene zaštite, Novi Sad, Republika Srbija

${ }^{5}$ Univerzitet u Novom Sadu, Medicinski fakultet, Katedra za socijalnu medicinu i zdravstvenu statistiku sa informatikom, Novi Sad, Republika Srbija

\section{Kratak sadržaj}

Ova studija je imala za cilj da prikaže demografske i hronološke karakteristike humane leptospiroze, kao i prostornu raspodelu ove bolesti 
u Autonomnoj Pokrajini Vojvodini, Srbija, u periodu između 2009. i 2018. godine i da ispita moguće veze između pojave bolesti i klimatskih faktora. Pored toga opisuje seroprevalenciju leptospiroze među domaćim životinjama $\mathrm{u}$ istom periodu i na istom području. Pirsonov test korelacije je korišćen za određivanje korelacije između različitih meteoroloških faktora i trendova $\mathrm{u}$ vremenskim serijama humanih slučajeva leptospiroze. U posmatranom desetogodišnjem periodu ukupno je registrovano 87 slučajeva humane leptospiroze sa pet smrtnih ishoda (Letalitet: 5,75\%). Prosečna godišnja stopa incidencije iznosila je 0,45/100.000 (opseg: $0,16-1,50 / 100.000$ ). Bolest je češće registrovana kod osoba muškog pola $(\mathrm{M} / \check{Z}=16,40: 1)$, sa najvećim brojem slučajeva prijavljenih u avgustu $(\mathrm{N}=23 ; 26,44 \%)$, septembru $(\mathrm{N}=20$; $23,00 \%)$ i oktobru $(\mathrm{N}=15 ; 17,24 \%)$. Zabeležena je statistički značajna slaba korelacija pozitivnog smera između srednje mesečne temperature vazduha i broja humanih slučajeva leptospiroze po mesecima $(\mathrm{r}=0,30 ; p<0,01)$ i statistički značajna slaba korelacija pozitivnog smera između mesečnog broja humanih slučajeva i sume padavina u prethodnom mesecu $(\mathrm{r}=0,27$; $p<0,01)$. Prosečna godišnja seroprevalencija leptospiroze među domaćim životinjama iznosila je 1,13\% (opseg: 0,23\% - 3,65\%). Seroprevalenca kod mačaka, pasa, goveda, magaraca, konja, ovaca, svinja i koza iznosila je $25 \%, 9,50 \%, 8,55 \%, 6,25 \%, 1,59 \%, 0,25 \%, 0,18 \%, 0,00$, redom. Leptospiroza ljudi i životinja se beleži kontinuirano, što ukazuje na potrebu stalnog i kvalitetnog praćenja epidemiološke i epizootiološke situacije ove bolesti. Potrebno je sprovođenje sveobuhvatnijih uporednih studija karakteristika humane i animalne leptospiroze, kao i dodatnih studija životnih uslova životinja na farmama sa leptospirozom i opsežnijih studija koje će utvrditi uticaj klimatskih i ekoloških faktora na pojavu leptospiroze u Vojvodini.

Ključne reči: Humana leptospiroza, leptospiroza životinja, zoonoze, epidemiologija, seroprevalencija, jedno zdravlje.

\section{INTRODUCTION}

Leptospirosis is globally widespread zoonosis with a major impact on public health in all continents except Antarctica (Adler and de la Peña Moctezuma, 2010). The causative agent of leptospirosis is spiral-shaped bacteria belonging to the genus Leptospira, family Spirochetaceae (WHO, 2003). The disease belongs to the group of natural-focal infectious diseases, with a large number of reservoirs among domestic and wild animals (WHO, 2003). Rodents, especially 
rats are important asymptomatic Leptospira renal carriers (Levett, 2001). Animal-human transmission commonly occurs either by direct contact with the urine or tissues of infected animals or indirectly, through urine-contaminated environment, by penetrating through damaged skin or mucous membranes of eyes, mouth and nose (Antonijević, 2001; WHO, 2003). It is estimated that human leptospirosis can cause 1.03 million cases and 58,900 deaths each year, globally (Costa et al., 2015). The incidence of human leptospirosis ranges between $0.1-1$ cases/100,000 inhabitants per year in temperate, non-endemic areas and between $10-100$ cases/100,000 per year in humid, tropical, endemic areas (Sethi et al., 2010). For all these aspects, the "One Health" approach is of particular importance in solving problems related to zoonoses and achieving better prevention and control of these diseases because it includes multidisciplinary and multisectoral cooperation of different experts and connects humans, animals, plants and their common environment (Rabozzi et al., 2012).

The aim of this paper was to summarize the demographical and chronological characteristics of human leptospirosis and to determine the locations where the disease was identified, as well as to examine possible relationships between the occurrence of the disease and climatic factors in the Autonomous Province of Vojvodina (Vojvodina), Serbia, for the period between 2009 and 2018. We additionally described the seroprevalence of this disease among domestic animals in the same area and the same period.

\section{MATERIAL AND METHODS}

\section{Data collection}

Surveillance data for human cases were obtained from the Registry of Communicable Diseases, Centre for Disease Control and Prevention, Institute for Public Health of Vojvodina (IPHV), Novi Sad and analyzed retrospectively. The sources of the data were individual case reports, epidemiological surveys and annual reports of the IPHV for the observed ten-year period (2009-2018). For notification of leptospirosis we used a case definition of the European Centre for disease Prevention and control (ECDC, 2018). Veterinary data were obtained from the Scientific Veterinary Institute "Novi Sad" and Veterinary Specialized Institutes Sombor, Zrenjanin, Subotica and Pančevo. Meteorological data were obtained from annual reports of the Republic Hydrometeorological Service of Serbia (RHMS, 2019). These data include the mean annual air temperatures (in degrees Celsius), relative air humidity (in percent), the average annual precipitation (in $\mathrm{mm}$ ) and numbers of rainy days, provided by 
12 measuring stations located in the territory of Vojvodina. Demographic data was downloaded from the Statistical Office of the Republic of Serbia website (RZS, 2014).

\section{Laboratory procedures}

Laboratory diagnosis of human leptospirosis was confirmed by microscopic agglutination test (MAT) using the panels of Leptospira serovars or by polymerase chain reaction (PCR) at the Scientific Veterinary Institute "Novi Sad", specialized Veterinary Institutes in Subotica, Sombor and Zrenjanin, and by the enzyme-linked immunosorbent assay (ELISA) at the Institute of Public Health of Serbia (only human samples from South Banat district). For MAT, a four-fold increase in antibody titres in paired human serum samples or a single serum with titre $\geq 1: 100$ in a patient with clinical presentation of leptospirosis were considered as positive. Samples from pigs, cattle, sheep, horses, and goats were examined during the regular monitoring of animal health ordered by the Annual program of measures for each year on the territory of the Republic of Serbia (MAFWM). Dog and cat samples were tested only if animals had leptospirosis-like symptoms in case of travelling abroad to countries requesting such analysis. The detection of antibodies to Leptospira in animals was performed using MAT (cut-off 1:100).

\section{Data analysis}

Descriptive analysis was used to summarize demographic and chronological characteristics of human cases of leptospirosis, and by district of patient's residence. Annual incidence rate was calculated as the number of human cases per 100,000 individuals at risk for the observed period. Animal seroprevalence was calculated as the percentage of test-positive animals among the total number of tested animals. We used the Pearson's correlation to explore potential correlations between different meteorological factors and trends in time-series of leptospirosis cases. Analyses were performed using Stata, v16 (STATA StataCorp, College Station, TX, USA) and Quantum GIS (QGIS) version 3.4 was used for mapping. A $p<0.05$ was considered statistically significant.

\section{RESULTS}

A total of 87 human cases of leptospirosis were recorded during the observed ten-year period in Vojvodina. The average annual incidence rate was 
0.45/100,000 (range from $0.16 / 100,000$ in 2015 and 2018, to $1.50 / 100,000$ in 2014) (Figure 1). All registered cases occurred sporadically. Only one case of human leptospirosis was imported from neighbouring Croatia, while all others were autochthonous.

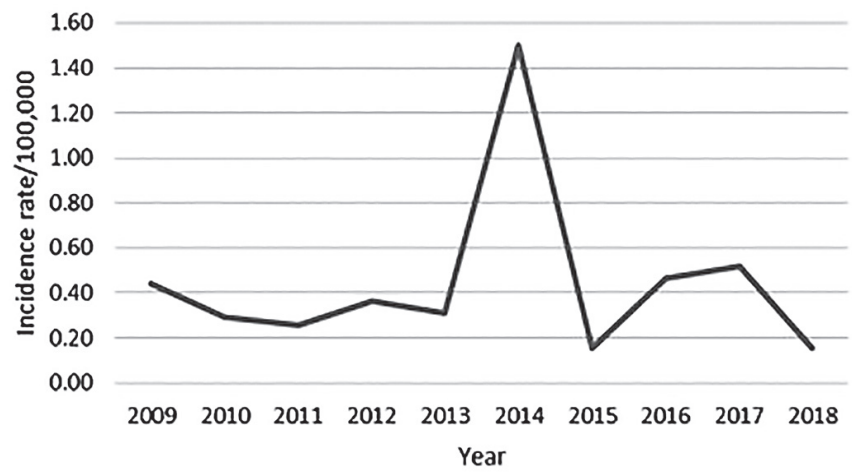

Figure 1. Incidence rate of human leptospirosis in Vojvodina, Serbia, in the period 2009-2018

The disease was more prevalent in males $(\mathrm{M} / \mathrm{F}=16.40: 1)$. The age distribution of human cases showed an age-specific incidence peak in the age group 40 - 49, followed by age groups $\geq 60$ and 50 - 59 years $(1.74 / 100,000 ; 1.59 / 100,000$ and 1.01/100,000, respectively) (Figure 2). Among males, the highest incidence rate occurred in the age group $40-49(1.74 / 100,000)$, while in females the incidence peaked in the $50-59$ age group $(0.12 / 100,000)$. There were five deaths related to leptospirosis, giving the overall case fatality rate (CFR) of $5.75 \%$. Deaths occurred more often in males $(\mathrm{M} / \mathrm{F}=4: 1)$ and in the age group over 60 years $(\mathrm{N}=3 ; 60 \%)$.

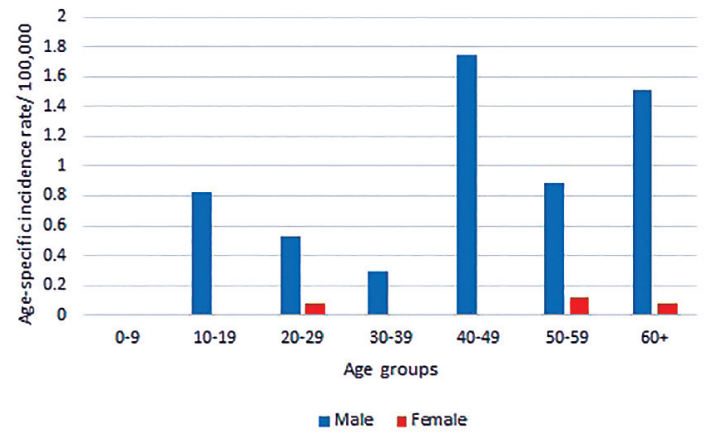

Figure 2. Distribution of human leptospirosis in Vojvodina, Serbia, in the period 2009-2018 by age and gender 
Figure 3 reveals the incidence rate of leptospirosis per 100,000 inhabitants across the districts of Vojvodina. Human leptospirosis was registered in all seven Vojvodina districts, with the highest incidence rate in South Bačka $(0.88 / 100,000)$ and West Bačka $(0.74 / 100,000)$.
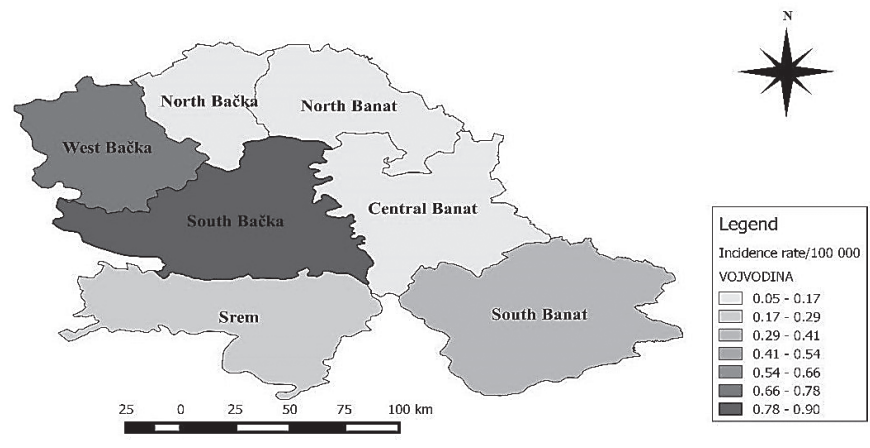

Figure 3. Distribution of human leptospirosis in Vojvodina, Serbia, in the period 2009-2018, by district of residence

The human leptospirosis revealed an extremely seasonal character with majority of cases reported in August $(\mathrm{N}=23 ; 26.44 \%)$, September $(\mathrm{N}=20$; $23 \%)$ and October $(\mathrm{N}=15 ; 17.24 \%)$. There were no human cases registered in January and February (Figure 4).

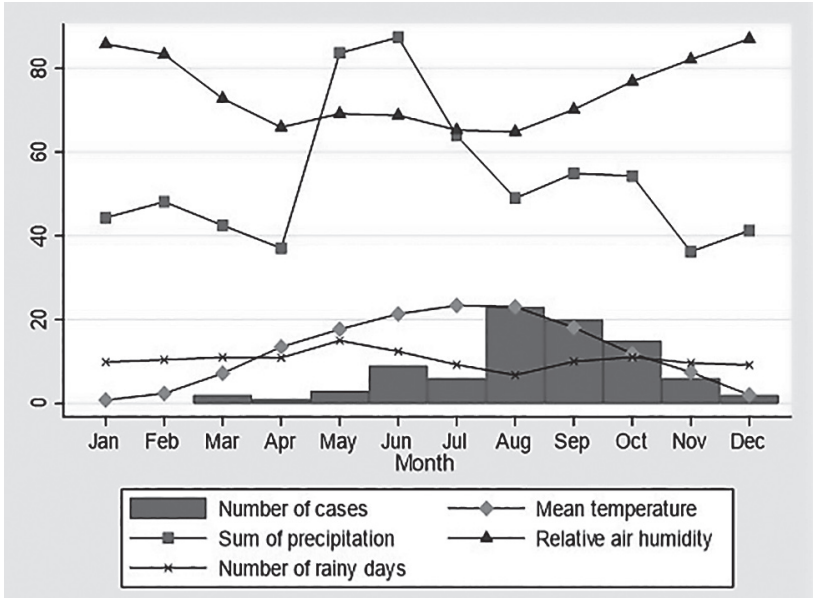

Figure 4. Seasonal distribution of human leptospirosis and the mean air temperature, the relative humidity, the sum of precipitation and the number of rainy days per month in Vojvodina, Serbia, in the period 2009-2018 
The correlation of the explored meteorological factors and the seasonality of human leptospirosis is shown in Figures 4 and 5. A statistically significant weak positive correlation was observed between the mean monthly air temperature and the number of human cases of leptospirosis of the same month ( $\mathrm{r}$ $=0.30, p<0.01)$. However, no significant correlation was found between the monthly number of human cases of leptospirosis and the sum of precipitation and the relative humidity by the same month $(\mathrm{r}=0.11, p=0.25 ; \mathrm{r}=-0.13, p=$ 0.17 , respectively). In order to account for a potential lag effect of these meteorological factors, we considered one-month delay and found a statistically significant weak positive correlation between the number of human cases and the sum of precipitation in the previous month $(\mathrm{r}=0.27, p<0.01)$ and a significant weak negative correlation of human cases with relative humidity in the previous month $(\mathrm{r}=-0.20, p=0.02)$.

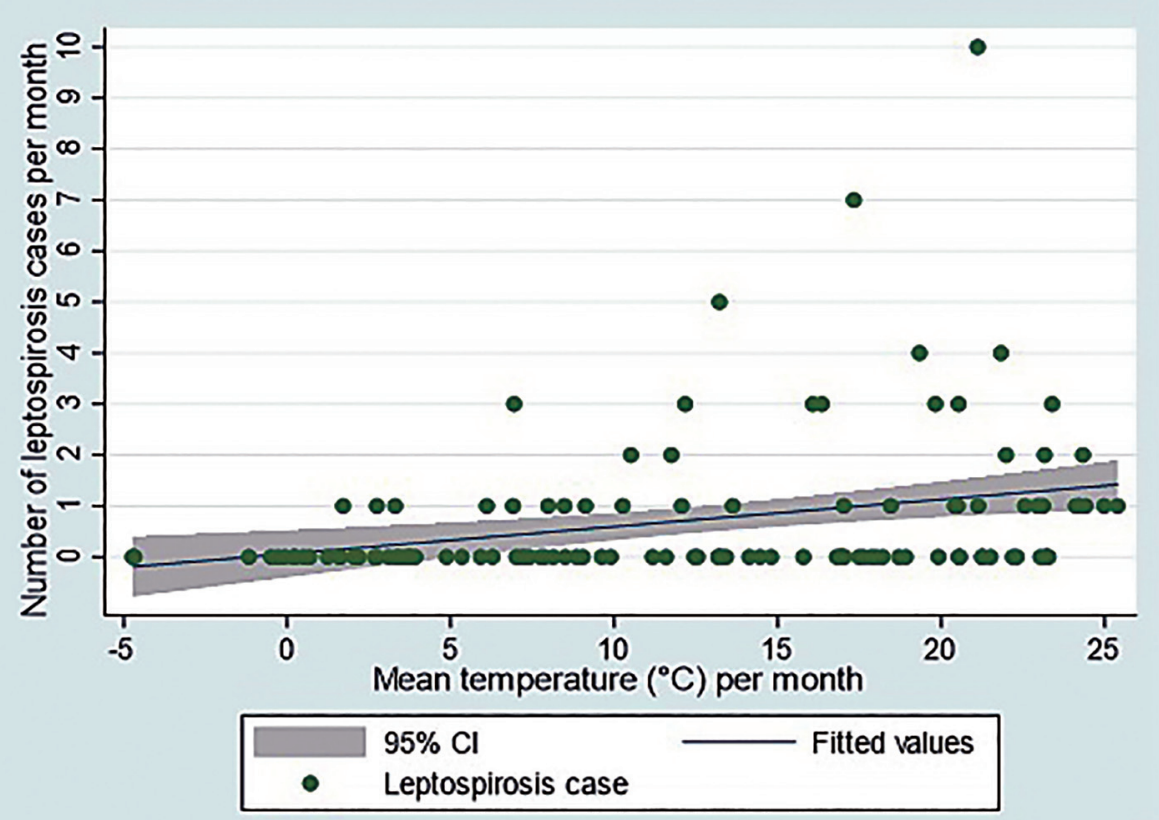

Figure 5. Correlation between the mean monthly temperature and the human cases of leptospirosis by month in Vojvodina, Serbia, for the period 2009-2018

During the observed ten-year period, a total of 220,875 domestic animals were examined. Seroprevalence of leptospirosis varied considerably (Table 1). The average annual seroprevalence was $1.13 \%$, ranging from $0.23 \%$ (in 2017) to $3.65 \%$ (in 2015). There were no seropositive goats, and the seroprevalence varied from the lowest $(0.18 \%)$ in pigs to the highest $(25 \%)$ in cats. 
Table 1. Seroprevalence of leptospirosis in domestic animals in Vojvodina, Serbia, in the period 2009-2018

\section{Animal}

Years

\begin{tabular}{|c|c|c|c|c|c|c|c|c|c|c|c|c|}
\hline \multirow{2}{*}{\multicolumn{2}{|c|}{2009}} & & & & & & & & & & & \\
\hline & & 2010 & 2011 & 2012 & 2013 & 2014 & 2015 & 2016 & 2017 & 2018 & Total & \\
\hline \multirow{3}{*}{ Pigs } & E & 28,130 & 23,112 & 25,189 & 20,368 & 15,767 & 18,675 & 16,350 & 14,809 & 14,599 & 15,867 & 7192,866 \\
\hline & $\mathbf{P}$ & 29 & 32 & 75 & 35 & 11 & 10 & 133 & 9 & 1 & 14 & 349 \\
\hline & $\%$ & 0.10 & 0.14 & 0.30 & 0.17 & 0.07 & 0.05 & 0.81 & 0.06 & 0.01 & 0.09 & 0.18 \\
\hline \multirow{3}{*}{ Cattle } & $\mathbf{E}$ & 4,231 & 2,957 & 7,251 & 3,695 & 749 & 1,394 & 1,787 & 1,238 & 751 & 642 & 24,695 \\
\hline & $\mathbf{P}$ & 193 & 675 & 152 & 57 & 47 & 291 & 530 & 92 & 26 & 49 & 2,112 \\
\hline & $\%$ & 4.56 & 22.83 & 2.10 & 1.54 & 6.28 & 20.88 & 29.66 & 7.43 & 3.46 & 7.63 & 8.55 \\
\hline \multirow{3}{*}{ Sheep } & $\mathrm{E}$ & 141 & 10 & 76 & 797 & 99 & 5 & 23 & 6 & 1 & 27 & 1185 \\
\hline & $\mathbf{P}$ & 1 & 0 & 0 & 0 & 0 & 0 & 0 & 0 & 0 & 2 & 3 \\
\hline & $\%$ & 0.71 & 0.00 & 0.00 & 0.00 & 0.00 & 0.00 & 0.00 & 0.00 & 0.00 & 7.41 & 0.25 \\
\hline \multirow{3}{*}{ Horses } & $\mathrm{E}$ & 183 & 177 & 184 & 86 & 152 & 61 & 52 & 83 & 66 & 86 & 1130 \\
\hline & $\mathbf{P}$ & 0 & 0 & 2 & 1 & 1 & 0 & 1 & 10 & 0 & 3 & 18 \\
\hline & $\%$ & 0.00 & 0.00 & 1.09 & 1.16 & 0.66 & 0.00 & 1.92 & 12.05 & 0.00 & 3.49 & 1.59 \\
\hline \multirow{3}{*}{ Goats } & $\mathrm{E}$ & 1 & 3 & 3 & 0 & 0 & 408 & 30 & 0 & 1 & 315 & 761 \\
\hline & $\mathbf{P}$ & 0 & 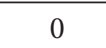 & 0 & 0 & 0 & 0 & . & 0 & 0 & 0 & 0 \\
\hline & $\%$ & 0.00 & 0.00 & 0.00 & 0.00 & 0.00 & 0.00 & 0.00 & 0.00 & 0.00 & 0.00 & 0.00 \\
\hline \multirow{3}{*}{ Dogs } & $\mathrm{E}$ & 15 & 20 & 22 & 6 & 76 & 9 & 8 & 9 & 25 & 10 & 200 \\
\hline & $\mathbf{P}$ & 2 & 0 & 0 & 1 & 0 & 4 & 1 & 1 & 9 & 1 & 19 \\
\hline & $\%$ & 13.33 & 0.00 & 0.00 & 16.67 & 0.00 & 44.44 & 12.50 & 11.11 & 36.00 & 10.00 & 9.50 \\
\hline \multirow{3}{*}{ Donkeys } & $\mathrm{E}$ & 0 & 0 & 0 & 0 & 0 & 6 & 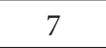 & 0 & 3 & 0 & 16 \\
\hline & $\mathbf{P}$ & 0 & 0 & 0 & 0 & 0 & 0 & 1 & 0 & 0 & 0 & 1 \\
\hline & $\%$ & 0.00 & 0.00 & 0.00 & 0.00 & 0.00 & 0.00 & 14.29 & 0.00 & 0.00 & 0.00 & 6.25 \\
\hline \multirow{3}{*}{ Cats } & $\mathrm{E}$ & 0 & 0 & 0 & 0 & 0 & 0 & 0 & 1 & 1 & 2 & 4 \\
\hline & $\mathbf{P}$ & 0 & 0 & 0 & 0 & 0 & 0 & 0 & 0 & 0 & 1 & 1 \\
\hline & $\%$ & 0.00 & 0.00 & 0.00 & 0.00 & 0.00 & 0.00 & 0.00 & 0.00 & 0.00 & 50.00 & 25.00 \\
\hline \multirow{3}{*}{ Total } & $\mathrm{E}$ & 32,701 & 26,279 & 32,725 & 24,952 & 16,843 & 20,558 & 18,257 & 16,146 & 15,447 & 16,949 & 22,0857 \\
\hline & $\mathbf{P}$ & 225 & 707 & 229 & 94 & 59 & 305 & 666 & 112 & 36 & 70 & 2,503 \\
\hline & $\%$ & 0.69 & 2.69 & 0.70 & 0.38 & 0.35 & 1.48 & 3.65 & 0.69 & 0.23 & 0.41 & 1.13 \\
\hline
\end{tabular}

\section{DISCUSSION}

This study analysed the most important epidemiological and epizootiological characteristics of leptospirosis in Vojvodina over a ten-year period. As leptospirosis is an important public health problem, the analysis by "One health" 
approach contributes to a better understanding of the disease dynamics. Thus, these findings might be relevant for timely planning and improving prevention and control measures against leptospirosis. To the best of our knowledge, this is the first study that shows the frequency of leptospirosis in humans in parallel to animals at the level of the entire Province, and the first one that analysed the seroprevalence in domestic animals including data from all epizootic areas of Vojvodina.

The average annual incidence of human leptospirosis was 1.6 times lower than that recorded during the previous 10-year period (2000 - 2009) in Vojvodina (Ristić et al., 2010), and 1.7 times lower than the one registered in Serbia in the period 2014 - 2018 (IPHS, 2018). On the other hand, the incidence of human leptospirosis was three times higher compared to incidence registered in the countries of the European Union (0.21/100,000 inhabitants) in the same period (ECDC, 2019). The highest incidence rate of leptospirosis was registered in 2014, when floods hit Serbia and the neighbouring countries. Some studies have already pointed to the importance of heavy seasonal rainfall and floods in the triggering of leptospirosis outbreaks, which is primarily related to sewage spills, which serve as a source of food for rats (Reis et al., 2008; Lau et al., 2010; Allan, 2016). Also, wet soil after floods allows Leptospira to survive longer (Desvars et al., 2011).

Similar to the results of several previously published studies (Holk et al., 2000; Christova et al., 2003; Goris et al., 2013) we found that leptospirosis occurs more frequently among males than in females. This could be explained by the fact that males are in higher risk of the disease due to occupational exposure to the source of infection and men are more likely to participate in activities such as fishing and hunting than females. We further found that as many as $80 \%$ of all cases of leptospirosis in Vojvodina were registered in age groups over 40, which is similar to the demographic distribution reported in Bulgaria, Croatia and Germany (Christova et al., 2003; Jansen et al., 2005 Topic et al., 2010). Overall CFR was slightly lower than that recorded in the Netherlands and Bulgaria (Christova et al., 2003; Goris et al., 2013), but even four times higher than in neighbouring Croatia (Habus et al., 2017). High CFR is a consequence of underestimation of leptospirosis and recognition of mainly severe forms of the disease (hospitalized patients), in which CFR may exceed $50 \%$ (Costa et al., 2015). The distribution of leptospirosis across Vojvodina districts reveals the highest incidence rate in the Districts of South Bačka and West Bačka. A possible explanation for that is the rich hydrographic network of these parts of Vojvodina, which are suitable places for the survival of Leptospira (Svircev et al., 2009). Seasonal characteristics of leptospirosis are influenced by the intensity of contact with reservoirs, as well as with contaminated 
surface waters and soil (IPHV, 2018). Our results showed a seasonal peak of the disease in the summer and early autumn months (two thirds of cases were registered in August, September and October). A similar pattern has been found in Italy, Bulgaria, Croatia and other countries of the temperate climate zone (Ciceroni et al., 2000; Christova et al., 2003, Habus et al., 2017). We further found a positive correlation between the mean monthly air temperature and the monthly number of leptospirosis cases in Vojvodina. This correlation is mostly driven by frequent human outdoor activities, which include recreational activities (swimming and water sport activities), farming and garden activities during warm months. These activities increase the risk of human contact with contaminated water and reservoirs of infection, primarily rodents. Similar to our results, the positive correlation between human leptospirosis and rainfall in the previous month was established in the study in Martinique (Lhomme et al., 1996). This can be explained by the length of incubation period of the disease and the survival of the Leptospira for 1 - 2 months in the moist soil after rainfall.

The average annual seroprevalence of animal leptospirosis in Vojvodina was 1.5 times higher than in the study conducted in South Bačka district (1997 - 2001) (Grgić et al., 2003) and nine times lower than that observed in Croatia in the period 2009-2014 (Habus et al., 2017). Our results revealed a high percentage of seropositivity in cattle, that is, seven to nine times higher than in previous studies conducted in the South Backka District (Grgić et al., 2005) and in the city of Belgrade (Vojinović et al., 2014a). This could be due to the high population of rodents on cattle farms, but also to the extended Program of animal health protection measures, which also included the analysis of abortions as a new criterion from 2016. Furthermore, the percentage of seropositive horses was noticeably lower than previously demonstrated (Vojinović et al., 2009; Turk et al., 2013; Vera et al., 2020). Although overall $0.18 \%$ of pigs tested positive for leptospiral infection, the seropositivity was consistently maintained. This indicates the constant presence of the disease among these animals, as previously reported (Grgić et al. 2002, Vojinović et al., 2014b). There were no goats tested positive for leptospirosis, and seropositivity among sheep was low and registered discontinuously. This result is probably due to the small number of samples compared to cattle and pigs, but also to the fact that sheep and goats are more commonly kept in the open space then objects indoor over the year.

This study has some limitations that should be taken into account when interpreting our results. Firstly, the reported incidence rates of human cases are underestimated due to the use of passive surveillance data. Insufficient recognition and diagnosis of the disease leads to the registration of mainly hos- 
pitalized cases. Secondly, the overall number of examined pets (cats and dogs together) is still not high enough to draw out the exact conclusion. There is no program or obligation for testing these animals except if they are travelling abroad to the countries that require such type of analysis. Thirdly, the number of sheep, goat and donkey samples is pretty low compared to that of cattle and pigs, thus, the determined seroprevalence values should be considered with caution. Actually, it can be stated that the higher number of samples analyzed, the more credible information on seroprevalence.

\section{Conclusion}

Human and animal leptospirosis continuously occurs in Vojvodina, which implies the need for constant and thorough monitoring of the epidemiological and epizootic situation of this disease.

As the disease is often neglected and underestimated, that is, diagnosed mainly in hospitalized patients, education of physicians at all levels of health care system should be carried out in order to recognize and detect the disease in a timely manner. The presence of leptospirosis on cattle and pig farms should be considered a significant public health concern. Detailed studies of living conditions of animals on farms with leptospirosis have to be done, to establish whether there are other elements, besides rodents, which contribute to the presence of the disease on our farms. In order to develop the best prevention and control strategies against this disease, better surveillance of human leptospirosis and better animal monitoring are essential. Further, more comprehensive parallel studies in humans and animals are needed, as well as additional research to determine the influence of climatic/ environmental factors on the occurrence of leptospirosis in Vojvodina.

\section{ACKNOWLEDGEMENT}

We thank all colleagues from veterinary and human medicine who participated in the surveillance and monitoring of human and animal leptospirosis in Vojvodina, Serbia, during last ten years. Our special thanks to Tibor Molnar (Veterinary Specialized Institute Subotica, Serbia), Bratislav Kisin (Veterinary Specialized Institute Sombor, Serbia), Aleksandar Živulj (Veterinary Specialized Institute Pančevo, Serbia) and Vladimir Bursać (Veterinary Specialized Institute Zrenjanin, Serbia) for their invaluable contributions to this study. 


\section{Author's Contribution:}

PT and VV made contributions to conception and design of the article; PT and VV wrote the manuscript; RM and MS coordinated the work and revised the manuscript; SS and GŽ were involved in the data collection and revised the manuscript. PT and VV prepared the final draft; VV and TT performed statistical analysis, PT, RS and ŠM contributed in results analysis and the way of results presenting.

\section{Competing interest}

The authors declare that they have no competing interest.

\section{REFERENCES}

1. Adler B., de la Peña Moctezuma A. 2010. Leptospira and leptospirosis. Veterinary Microbiology, 140, 3/4, 287-296. doi: 10.1016/j.vetmic.2009.03.012.

2. Allan KJ. 2016. Leptospirosis in northern Tanzania: investigating the role of rodents and ruminant livestock in a neglected public health problem. Doctoral Thesis, University of Glasgow, Glasgow.

3. Antonijević B. 2001. Zoonoze, Eds. Đerić B.J., Pijanović P., Zavod za udžbenike i nastavna sredstva, Beograd, Serbia, ${ }^{\text {st }}$ edition, ISBN 978-86-17362971.

4. Christova I., Tasseva E., Manev H. 2003. Human leptospirosis in Bulgaria, 1989-2001: epidemiological, clinical, and serological features. Scandinavian Journal of Infectious Disease, 35, 11/12, 869-872. doi: 10.1080/00365540310016709.

5. Ciceroni L., Stepan E., Pinto A., Pizzocaro P., Dettori G., Franzin L., Lupidi R., Mansueto S., Manera A., Ioli A., Marcuccio L., Grillo R., Ciarrocchi S., Cinco M. 2000. Epidemiological trend of human leptospirosis in Italy between 1994 and 1996. European Journal of Epidemiology, 16, 1, 79-86. doi: 10.1023/a:1007658607963.

6. Costa F., Hagan J.E., Calcagno J., Kane M., Torgerson P., Martinez-Silveira M.S., Stein C., Abela-Ridder B., Ko A.I. 2015. Global Morbidity and Mortality of Leptospirosis: A Systematic Review. PLoS Neglected Tropical Diseases, 9, 9, e0003898. doi: 10.1371/journal.pntd.0003898.

7. Desvars A., Jégo S., Chiroleu F., Bourhy P., Cardinale E., Michault A. 2011. Seasonality of human leptospirosis in Reunion Island (Indian Ocean) and its association with meteorological data. PLoS One, 6, 5, e20377. doi: 10.1371/journal.pone.0020377. 
8. European Centre for Disease Prevention and Control (ECDC). 2018. EU Case definition. Available at: https://www.ecdc.europa.eu/en/surveillanceand-disease-data/eu-case-definitions Accessed 09.05.2021.

9. European Centre for Disease Prevention and Control (ECDC). 2019. Surveillance Atlas of Infectious Diseases. Available at: https://atlas.ecdc.europa.eu/public/index.aspx Accessed 05.05.2021.

10. Goris M.G., Boer K.R., Duarte T.A., Kliffen S.J., Hartskeerl R.A. 2013. Human leptospirosis trends, the Netherlands, 1925-2008. Emerging Infectious Diseases, 19, 3, 371-378. doi: 10.3201/eid1903.111260.

11. Grgić Ž., Vidić B., Đuričić B., Savić-Jevđenić S., Stojanov I. 2005. Findings of specific antibodies against Leptospira interrogans in cattle blood sera. Veterinarski Glasnik, 59, 5/6, 611-618. doi: 10.2298/VETGL0506611G.

12. Grgić Ž., Vidić B., Savić-Jevđenić S., Stojanov I. 2002. Swine leptospirosis in Southern Bačka district from 1997 to 2001 . Veterinarski glasnik, 56, 3/4, 195-202. doi:10.2298/VETGL0204195G.

13. Grgić Ž., Vidić B., Savić-Jevđenić S., Stojanov I. 2003. Leptospirosis in domestic animals. Savremena Poljoprivreda, 52, 3/4, 459-464.

14. Habus J., Persic Z., Spicic S., Vince S., Stritof Z., Milas Z., Cvetnic Z., Perharic M., Turk N. 2017. New trends in human and animal leptospirosis in Croatia, 2009-2014. Acta Tropica, 168, 1-8. doi:10.1016/j.actatropica.2017.01.002.

15. Holk K., Nielsen S.V., Rønne T. 2000. Human leptospirosis in Denmark 1970-1996: an epidemiological and clinical study. Scandinavian Journal of Infectious Diseases, 32, 5, 533-538. doi: 10.1080/003655400458839.

16. Institute of Public Health of Serbia (IPHS). 2018. Infectious Disease Report in the Republic of Serbia for 2018. Available at: http://www.batut. org.rs/download/izvestaji/GodisnjiIzvestajOZaraznimBolestima2018.pdf Accessed 08.05.2021.

17. Institute of Public Health of Vojvodina (IPHV). 2018. Communicable diseases in AP Vojvodina in 2018-Annual report. Available at: http://izjzv. org.rs/publikacije/ZarazneBolesti/ZB_2018.pdf Accessed 10.05.2021.

18. Jansen A., Schöneberg I., Frank C., Alpers K., Schneider T., Stark K. 2005. Leptospirosis in Germany, 1962-2003. Emerging Infectious Diseases, 11, 7, 1048-1054. doi: 10.3201/eid1107.041172.

19. Lau C.L., Smythe L.D., Craig S.B., Weinstein P. 2010. Climate change, flooding, urbanisation and leptospirosis: fuelling the fire? Transactions of The Royal Society of Tropical Medicine and Hygiene, 104, 10, 631-638. doi: 10.1016/j.trstmh.2010.07.002.

20. Levett PN. 2001. Leptospirosis. Clinical Microbiology Review, 14, 2, 296326. doi:10.1128/CMR.14.2.296-326.2001. 
21. Lhomme V., Grolier-Bois L., Jouannelle J., Elisabeth L. 1996. Leptospirosis in Martinique from 1987 to 1992: results of an epidemiological, clinical and biological study. Médecine et Maladies Infectieuses, 26, 2, 94-98. doi:10.1016/S0399-077X(96)80161-2.

22. Ministry of Agriculture, Forestry and Water Management of the Republic of Serbia (MAFWM). Rulebook on determining the Program of animal health protection measures. Available at: http://www.minpolj.gov.rs/dokumenti/pravilnici/ Accessed 15.05.2021.

23. Rabozzi G., Bonizzi L., Crespi E., Somaruga C., Sokooti M., Tabibi R., Vellere F., Brambilla .G., Colosio C. 2012. Emerging zoonoses: the "one health approach". Safety and Health at Work, 3, 1, 77-83. doi: 10.5491/ SHAW.2012.3.1.77.

24. Reis R.B., Ribeiro G.S., Felzemburgh R.D., Santana F.S., Mohr S., Melendez A.X., Queiroz A., Santos A.C., Ravines R.R., Tassinari W.S., Carvalho M.S., Reis M.G., Ko A.I. 2008. Impact of environment and social gradient on Leptospira Infection in urban slums. PLoS Neglected Troical Disease, 2, 4, e228. doi: 10.1371/journal.pntd.0000228.

25. Republic Hydrometeorological Service of Serbia (RHMS). 2019. Available at: http://www.hidmet.gov.rs/eng/meteorologija/klimatologija.php Accessed 03.05.2021.

26. Ristić M., Šeguljev Z., Vidić B., Petrović V., Ilić S. 2010. Structure and distribution of leading zoonoses in Vojvodina in 2000-2009 period. Archive of Veterinary Medicine, 3, 1, 63-72. doi:10.46784/e-avm.v3i1.193.

27. Sethi S., Sharma N., Kakkar N., Taneja J., Chatterjee S.S., Banga S.S., Sharma M. 2010. Increasing trends of leptospirosis in northern India: a clinicoepidemiological study. PLoS Neglected Tropical Diseases, 4, 1, e579. doi: 10.1371/journal.pntd.0000579.

28. Statistical Office of Republic of Serbia (RZS). 2014. Census Atlas, 2011. Available at: https://publikacije.stat.gov.rs/G2014/PdfE/G20144012.pdf Accessed 03.05.2021.

29. Svircev Z., Marković S.B., Vukadinov J., Stefan-Mikić S., Ruzić M., Doder R., Fabri M., Canak G., Turkulov V., Stojanović D.B., Draganić M. 2009. Leptospirosis distribution related to freshwater habitats in the Vojvodina region (Republic of Serbia). Science China Life Sciences, 52, 10, 965-971. doi: 10.1007/s11427-009-0124-2.

30. Topic M.B., Habus J., Milas Z., Tosev E.C., Stritof Z., Turk N. 2010. Human leptospirosis in Croatia: current status of epidemiology and clinical characteristics. Transactions of The Royal Society of Tropical Medicine and Hygiene, 104, 3, 202-206. doi: 10.1016/j.trstmh.2009.05.018. 
31. Turk N., Milas Z., Habuš J., Štritof Majetić Z., Mojčec Perko V., Barbić Lj., Stevanović V., Perharić M., Starešina, V. 2013. Equine leptospirosis in Croatia - occurrence of subclinical infections and abortions. Veterinarski arhiv, 83, 3, 253-262.

32. Vera E., Taddei S., Cavirani S., Schiavi J., Angelone M., Cabassi C.S., Schiano E., Quintavalla F. 2020. Leptospira Seroprevalence in Bardigiano Horses in Northern Italy. Animals, 10, 1, 23. doi:10.3390/ani10010023.

33. Vojinović D., Žutić J., Stanojević S. 2009. Seroprevalence of leptospirosis in horses in the territory of Belgrade during the period from 1998 to 2008. Veterinarski Glasnik, 63, 3/4, 163-169. doi:10.2298/VETGL0904163V.

34. Vojinović D., Jovičić D., Đuričić B., Ilić Ž., Samokovlija A. 2014a. Leptospira infections in cattle at the territory of Belgrade in the period from 2000. to 2010. Veterinarski Glasnik, 68, 1/2, 11-22. doi:10.2298/VETGL1402011V.

35. Vojinović D., Vasić A., Jovičić D., Đuričić B., Ilić Ž. 2014b. Pigs leptospirosis at the territory of Belgrade. In Serbian. Veterinarski Glasnik, 68, 5/6, 331-338. doi:10.2298/VETGL1406331V.

36. World Health Organization. 2003. Human leptospirosis: guidance for diagnosis, surveillance and control. Available at: https://apps.who.int/iris/ handle/10665/42667 Accessed 02.05.2021.

Received: 10.06.2021.

Accepted: 22.07.2021. 